\title{
PROBLEMATIKA PELAKSANA TUGAS (PLT) DALAM MASA TRANSISI PEMERINTAHAN (PRA DAN PASCA PILKADA SERENTAK)
}

\author{
Nandang Alamsah Deliarnoor \\ e-mail:nandangalamsah@gmail.com
}

\begin{abstract}
ABSTRAK
Tulisan ini menggambarkan tentang masalah yang sedang hangat-hangatnya di Indonesia, yaitu mengenai permasalahan pelaksana tugas (plt) dalam masa transisi pemerintahan nanti (pra dan pasca Pilkada serentak). Pilkada serentak menjadi suatu permasalahan ketika adanya kekosongan jabatan Kepala Daerah definitif yang nantinya akan diganti oleh pelaksana tugas, menjadi masalah karena ada beberapa daerah yang akan dipimpin oleh plt selama kurang lebih dua tahun. Kewenangan pltyang terbatas akan mengakibatkan terhambatnya roda pemerintahan, sehingga perlu diatur peraturan yang tegas mengenai plt, baik itu berkaitan dengan wewenangnya maupun perlindungan hukumnya.

Metode yang digunakan dalam penulisan karya ilmiah ini adalah metode penelitian yuridis normatif dan kualitatif yang dikaji secara holistik kontekstual progresif. Holistik digunakan karena peraturan-peraturan yang ada maupun yang akan dibuat harus dikaji titik tautnya dengan peraturan dan aspek-aspek yang lain, terutama untuk melihat apakah kelemahan dan kekuatan peraturan yang ada ketika diimplementasikan pada kondisi nyata.

Perlu adanya kepastian hukum mengenai plt, agar roda pemerintahan tidak terhambat. Pengaturan mengenai plt bisa dilakukan melalui Diskresi atau PP dari UU Nomor 1 tahun 2015 tentang Penetapan Peraturan Pemerintah Pengganti Undang-Undang Nomor 1 Tahun 2014 tentang Pemilihan Gubernur, Bupati, dan Walikota menjadi Undang-Undang.
\end{abstract}

Kata Kunci: Kepala Daerah, Pilkada serentak, Pelaksana Tugas (plt), Kewenangan.

\section{ABSTRACT}

This writing will describe the problem that raged in Indonesia, a problem aboutcarateker (plt) transitional government (pre and postelections simultaneously). The elections simultaneously become a problem when the Defenitive Regional Head 
vacancy that will be replaced by carateker, a problem because there are some regions will be led by carateker for approximately two years. Authority carateker is limited and that will lead to delays in the wheels of government, so the need to set strict rules regarding the carateker, whether it relates to jurisdiction or legal protection.

The methods been using in this scientific writing is the research method of juridical normative and the qualitative, which has been examined in holistic contextual progressive. Holistic used because of the existing regulations nor that will be made, need to be assessed to another constitutions and another aspects. Especially to see the weakness and the strenght of existing regulations, when implemented starting in real conditions.

It needs a legal certainty regarding the carateker, so that the wheels of government are not obstructed. Settings on the carateker can be done through discretion or PP needs to be re-depth study of Law No. 1 of 2015 concerning Government Regulation in Lieu of Law No. 1 of 2014 concerning Election of governors, regents, and mayors become a Law.

Keywords: Regional Head, Elections Simultaneously, The Carateker, Authority.

\section{Pendahuluan}

Permasalahan Pilkada serentak bukan merupakan suatu hal yang baru, karena wacana tersebut sudah digulirkan pada masa pemerintahan SBY oleh wakil presiden HM Jusuf Kalla. Pada saat itu, rencana tersebut ditolak karena dianggap hanya sebatas perspektif efisiensi (penghematan anggaran) dibandingkan perspektif pembangunan politik. Namun, saat sekarang ini wacana tersebut sudah menjadi kenyataan dalam bentuk keputusan politik yang harus diimplementasikan ${ }^{99}$.

Dengan dikeluarkannya Peraturan Pemerintah Pengganti UndangUndang (Perpu) No. 1 Tahun 2014 tentang Pemilihan Gurbernur, Bupati, dan Walikota menjadi Undang-Undang (UU) Nomor 1 Tahun 2015 tentang Penetapan Perpu Nomor 1 Tahun 2014 tentang Pemilihan Gubernur, Bupati, dan Walikota, menjadi dasar hukum pelaksanaan Pilkada serentak di Indonesia. Hal ini tercantum dalam Pasal 3 ayat (1) Perpu No 1 Tahun

99 TOR LAN RI, 2015. 
2014 yang berbunyi: Pemilihan dilaksanakan setiap 5 (lima) tahun sekali secara serentak di seluruh wilayah Negara Kesatuan Republik Indonesia (NKRI). Jadwal Pilkada serentak berubah setelah terjadi perubahan pada UU Nomor 1 Tahun 2015 menjadi UU Nomor 8 Tahun 2015. Jadwal Pilkada serentak yaitu:

Tabel 1 Waktu Pelaksanaan Pilkada Serentak

\begin{tabular}{|c|c|c|c|}
\hline \multirow{2}{*}{$\begin{array}{c}\text { Akhir Masa } \\
\text { Jabatan } \\
\text { Kepala } \\
\text { Daerah }\end{array}$} & \multicolumn{2}{|c|}{$\begin{array}{c}\text { Waktu Pelaksanaan } \\
\text { Pilkada Serentak }\end{array}$} \\
\cline { 2 - 4 } & $\begin{array}{c}\text { Transisi } \\
\text { I }\end{array}$ & $\begin{array}{c}\text { Transisi } \\
\text { II }\end{array}$ & $\begin{array}{c}\text { Transisi } \\
\text { III }\end{array}$ \\
\hline $\begin{array}{c}\text { Tahun 2015 } \\
\text { dan Januari } \\
\text { s.d. Juni } \\
\text { 2016 }\end{array}$ & $\begin{array}{c}\text { Desember } \\
2015\end{array}$ & 2020 & \\
\hline $\begin{array}{c}\text { Juli s.d. } \\
\text { Desember } \\
\text { 2016 dan } \\
\text { Tahun 2017 }\end{array}$ & Februari & 2022 & \\
\hline & 2017 & & \\
\hline $\begin{array}{c}\text { Tahun 2018 } \\
\text { dan 2019 }\end{array}$ & Juni 2018 & 2023 & \\
& & & \\
\hline
\end{tabular}

Salah satu tujuan dari dilaksanakan Pilkada serentak ini adalah untuk efisiensi anggaran. Namun, diberlakukan Pilkada serentak ini menimbulkan pro dan kontra dalam masyarakat, karena akan ada beberapa wilayah yang akan dipimpin oleh pelaksana tugas (plt) yang menggantikan Kepala Daerah definitif yang habis masa jabatannya sebelum Pilkada serentak dimulai. Berdasarkan pada data Kemendagri, Pemilukada serentak 9 Desember 2015 mengakibatkan kekosongan 66 kursi kepala daerah, yaitu 7 Gubernur dan 59 Bupati atau Walikota yang habis masa jabatannya sebelum Pilkada dilakukan ${ }^{100}$. Bandingkan dengan data yang disampaikan Randy Ghalib: ${ }^{101}$

"SEBENTAR lagi akan ada sekitar 269 Kepala Daerah yang habis atau 'dihabiskan' masa jabatannya. Saya segaja menggunakan kata 'Habis' dan 'Dihabiskan' karena memang faktanya ada kepala daerah yang masa baktinya habis di tahun 2015 ini, namun tak sedikit pula yang masa baktinya baru berakhir di tahun 2016. Adapun rincian 269 kepala daerah yang habis dan dihabiskan masa baktinya untuk keperluan pemilihan kepala daerah secara serentak tahap pertama pada 9 Desember 2015 mendatang terdiri dari 9 Pilkada Gubernur, 224 Pilkada Bupati dan 36 Pilkada Walikota."

Maksud dari penunjukan plt pada beberapa daerah untuk menggantikan Kepala Daerah definitif, agar roda pemerintahan terus berjalan. Namun

100 http://www.otda.kemendagri.go.id/, diakses tanggal 24 Agustus 2015.

101 Randy Ghalib, Memahami Kewenangan Plt atau Pj Kepala Daerah, Diposting 07 Agustus 2015, 14:38:24 Dibaca : 302, Diunduh tanggal 10 September 2015 oleh Penulis. 
pada faktanya, wewenang yang dimiliki oleh pelaksana tugas dibatasi karena ia tidak boleh mengambil tindakan atau kebijakan yang bersifat strategis sehingga hal inilah yang nantinya malah menghambat jalannya roda pemerintahan. Melihat fakta di atas, maka perlu adanya aturan yang jelas mengenai plt, baik itu berkaitan dengan wewenang, perlindungan hukum, kualifikasi untuk menjadi pelaksana tugas, serta bagi pelaksana tugas yang menyalahgunakan wewenangnya. Permasalahan ini menjadi sangat krusial mengingat banyaknya daerah yang dipimpin oleh plt, terutama daerah-daerah yang dijabat oleh plt selama dua tahun, dan jangan sampai pengangkatan plt bermuatan politis karena ia adalah pejabat pemerintah, yang bisa jadi menjadi kepanjangan tangan pemerintah pusat.

Berdasarkan fakta empiris pelaksanaan plt di beberapa tempat khususnya di Wilayah Jawa Barat, walaupun penyebab adanya plt ini adalah karena adanya pemekaran daerah, (sebelum terpilih kepala daerah definitif maka diangkat plt) seperti Kabupaten Bandung Barat dan Kabupaten Pangandaran menunjukkan adanya beberapa masalah. Berdasarkan wawancara dengan staf Gubernur Jawa Barat bidang hukum dan politik pemerintahan Prof. Dede Mariana, ${ }^{102}$ seperti terjadi di Bandung Barat waktu itu plt langsung membuat visi dan misi bahkan RPJP layaknya Kepala Daerah definitif, bahkan RPJP-nya ini dituangkan dalam Peraturan Bupati yang seharusnya dalam Peraturan Daerah. Demikian pula di Kabupaten Pangandaran, plt intens mengurus birokrasi (padahal plt tidak berwenang dalam hal mutasi pegawai). Beberapa kasus ini, yaitu tentang pembuatan RPJP dan masalah pengisian birokrasi, telah dianggap "off side" dari tugas dan wewenang plt. Oleh karena itu Dede Mariana setuju untuk dibuat aturan untuk merumuskan secara jelas apa yang dimaksud dengan plt tidak boleh mengambil "kebijakan strategis" tersebut. Apakah membuat RPJP itu termasuk kebijakan strategis katanya? Lebih jauh lagi menurut Dede Mariana bahwa persoalan pokok dari masalah plt ini adalah masalah "pemerintahan transisi" yang kalau tidak diatur dengan baik akan berdampak pada proses pemerintahan itu sendiri.

Berdasarkan hal-hal di atas maka beberapa pokok masalah yang hadir dari plt dalam masa transisi pemerintahan itu, yaitu:

1. Siapakah yang berhak mengangkat plt jika terjadi kekosongan jabatan kepala daerah selama masa transisi?

102 Prof. Dr. H. Dede Mariana, Drs., M.Si, Staf Gubernur Jawa Barat, Wawancara dilakukan pada hari Senin, 14 September 2015 di Bandung. 
2. Apa saja kualifikasi dari plt yang diangkat?

3. Sampai dimana batas kewenangan plt?

4. Apa yang dilakukan jika selama masa transisi diperlukan suatu kebijakan strategis, namun masih dijabat oleh plt?

5. Apa sanksi yang diberikan kepada plt yang melakukan sesuatu diluar kewenangan?

6. Bagaimana perlindungan hukum bagi plt dalam melaksanakan tugasnya?

\section{Tinjauan Pustaka}

Dalam suatu negara haruslah ada yang namanya pemerintahan dan pemerintah, karena pemerintah inilah yang akan menjalankan fungsi pemerintahan untuk mencapai tujuan negara.

Istilah pemerintah menurut Finer yang dikutip oleh Labolo menunjuk kepada empat pengertian pokok, yaitu:

1. Pemerintah merujuk pada suatu proses pemerintahan, dimana kekuasaan dioperasionalisasikan oleh mereka yang memegang kekuasaan secara sah. Dalam konteks itu, semua proses yang berlangsung dalam bingkai pengelolaan kekuasaan dipandang merupakan aktivitas yang menunjukkan pada peforma pemerintah.

2. Istilah pemerintah menunjuk pada keberadaan dimana proses pemerintahan tersebut berlangsung. Seringkali penamaan suatu entitas pemerintah menunjukkan secara langsung dimana pemerintah tersebut berada.

3. Pemerintah menunjukkan secara langsung person (orang) yang menduduki jabatan-jabatan pemerintah sebagai pelaksana kekuasaan.

4. Istilah pemerintah juga mengacu pada aspek bentuk, metode, atau sistem pemerintahan dalam suatu masyarakat, yakni struktur pengelolaan badan pemerintah serta hubungan antara yang memerintah dengan yang diperintah ${ }^{103}$.

Adapun pemerintahan secara etimologis berasal dari kata pemerintah sedangkan kata pemerintah berasal dari kata perintah. Pemerintahan menunjukkan pada aktivitas kekuasaan dalam berbagai ranah publik yang tidak saja merujuk pada pemerintah itu sendiri, namun juga berkaitan dengan aktivitas dalam berbagai konteks kelembagaan dengan tujuan mengarahkan, mengendalikan, serta mengatur semua hal yang berkaitan dengan ranah publik seperti kepentingan warga negara, pemiliki suara maupun para pekerja. ${ }^{104}$

103 Labolo, Muhammad. Memahami Ilmu Pemerintahan (Suatu Kajian, Teori, Konsep, dan Pengembangannya). Jakarta: PT. Raja Grafindo Persada. 2013. Hlm. 15-16.

104 Ibid., hlm 21. 
Dalam menjalankan roda pemerintahan, setiap daerah dipimpin oleh Kepala Daerah dan wakilnya. Adapun ketika Kepala Daerah dan wakil berhalangan sementara atau tetap maka roda pemerintahan dijalankan oleh plt sebagaimana yang dimaksudkan pada UU Nomor 30 Tahun 2014 tentang Administrasi Pemerintahan Pasal (1) dan (2). Kewenangan plt tidak sama dengan kewenangan Kepala Daerah definitif.

\section{Metode Kajian}

Metode yang digunakan dalam karya ilmiah ini adalah metode penelitian yuridis normatif dan kualitatif yang dikaji secara holistik kontekstual progresif. Holistik digunakan karena peraturan-peraturan yang ada maupun yang akan dibuat harus dikaji titik tautnya dengan peraturan dan aspek-aspek yang lain, terutama untuk melihat apakah kelemahan dan kekuatan peraturan yang ada ketika diimplementasikan pada kondisi nyata.

Dalam mengamati suatu masalah hukum, seorang juris biasanya memakai suatu pendekatan yang disebut pendekatan yuridisnormatif, artinya pengkajiannya didasarkan pada falsafah hukum, asasasas hukum, dan norma-norma hukum yang berlaku. Bagir Manan menyebut pendekatan ini dengan metode penelitian normatif, yaitu penelitian terhadap kaidah dan asas hukum (hukum positif). ${ }^{105}$ Bagir Manan juga membagi dua penelitian hukum, yaitu penelitian hukum murni dan terapan. Penelitian ini termasuk penelitian hukum terapan terutama mengenai penelitian evaluasi hukum. Bagir Manan menyebutkan bahwa evaluasi hukum itu bisa karena ada hukumnya tetapi tidak memadai lagi, karena kurang tepat cara-cara pengaturannya, atau memang belum ada aturannya. ${ }^{106}$

Secara garis besar pendekatan ini bisa diilustrasikan berangkat dari kajian norma-norma, kemudian menukik ke masyarakat (objek penelitian/masalah) dan kembali nanti hasilnya norma. Jadi secara singkat dirumuskan dengan :

$$
\begin{aligned}
& \mathrm{N}---------------M--------------N \\
& \mathrm{~N}=\text { Norma } \\
& \mathrm{M}=\text { Masyarakat }
\end{aligned}
$$

Penelitian kualitatif dilakukan untuk menganalisis dan menyajikan dunia sosial, dan perspektifnya di

105 Bagir Manan. Penelitian Di Bidang Hukum, artikel dalam Jurnal Hukum Puslitbangkum Lembaga Penelitian Universitas Padjadjaran Nomor Perdana : 1-1999, 1999, hlm. 9 106 Ibid'. 
dalam dunia, dari segi konsep, perilaku, persepsi, dan persoalan manusia yang diteliti. Menurut pendapat Moleong dalam bukunya Metode Penelitian Kualitatif mengatakan penelitian kualitatif:

"Penelitian kualitatif adalah suatu penelitian dimana data yang dikumpulkan berupa katakata, gambar, dan bukan angkaangka. Hal ini disebabkan adanya penerapan metode penelitian kualitatif. Dengan demikian laporan penelitian akan berisi kutipan data-data untuk memberikan gambaran penyajian laporan tersebut. Data tersebut mungkin berasal dari naskah wawancara, cacatan lapangan, foto, videotape, dokumen pribadi, catatan atau memo, dan dokumen resmi lainnya". ${ }^{107}$

Penelitian kualitatif berlatar ilmiah sebagai keutuhan mengandalkan analisis manusia sebagai alat (instrumen) penelitian, memanfaatkan metode kualitatif, mengandalkan analisis data secara induktif, mengarahkan sasaran penelitian pada upaya menemukan teori dasar, bersifat deskriptif, lebih mementingkan proses daripada hasil. Data dikumpulkan terutama melalui wawancara bebas sebagaimana dikemukakan Glaser dan Strauss bahwa: "Rumusan teori dari dasar, yaitu teori yang berasal dari data dan diperoleh secara analitik dan sistemik melalui metode komparatif". ${ }^{108}$

\section{Hasil dan Pembahasan}

Siapakah yang berhak mengangkat plt jika terjadi kekosongan jabatan kepala daerah selama masa transisi? Pengangkatan plt Gubernur diangkat oleh Presiden melalui usulan Menteri Dalam Negeri. Sedangkan pengangkatan Bupati/Walikota diangkat oleh Menteri Dalam Negeri melalui usulan oleh Gubernur. Adapun pengusulan pengangkatan penjabat sesuai dengan Surat Edaran Mendagri Nomor 120/3262/SJ, tanggal 17 Juni 2015, tentang Pemberhentian Kepala Daerah dan Wakil Kepala Daerah serta Pengangkatan Penjabat Kepala Daerah, sebagai berikut:

a. Pimpinan DPRD Provinsi mengusulkan pemberhentian Gubernur dan Wakil Gubernur kepada Presiden melalui Menteri Dalam Negeri dengan melampirkan risalah rapat paripurna dan keputusan DPRD Provinsi tentang pengumuman usul pemberhentian Gubernur dan Wakil Gubernur;

107 Moleong, Metodologi Penelitian Kualitatif, Bandung : PT Remaja Rosdakarya, 1989, hlm 6. 108 Ibid., hml 35. 
b. Pimpinan DPRD Kabupaten/Kota mengusulkan pemberhentian Bupati dan/atau Wakil Bupati atau Walikota dan/atau Wakil Walikota kepada Menteri Dalam Negeri melalui Gubernur dengan melampirkan risalah rapat paripurna dan keputusan DPRD Kabupaten/Kota tentang pengumuman usul pemberhentian Bupati dan/atau Wakil Bupati atau Walikota dan/atau Wakil Walikota;

c. Gubernur menyampaikan usul pemberhentian Bupati dan/atau Wakil Bupati atau Walikota dan/ atau Wakil Walikota;

d. Untuk mengisi kekosongan jabatan Bupati/Walikota, Gubernur mengusulkan 3 (tiga) orang nama calon Penjabat Bupati/ Penjabat Walikota kepada Menteri Dalam Negeri yang berasal dari jabatan pimpinan tinggi pratama, memiliki pengalaman di bidang pemerintahan, dan dapat menjaga netralitas PNS di dalam penyelenggaraan Pilkada dengan melampirkan SK Pangkat dan SK Jabatan terakhir serta biodata calon Penjabat Bupati/ Walikota;

e. Waktu pengusulan paling lambat 30 hari sebelum berakhirnya masa jabatan kepala daerah.

Adapun berdasarkan pada Pasal 173 ayat (2) dan (3) UU No. 8 Tahun 2015 disebutkan bahwa DPRD Provinsi dapat menyampaikan kepada Presiden penetapan Calon Gubernur yang berhalangan tetap atau berhenti atau diberhentikan berdasarkan putusan pengadilan yang telah memperoleh kekuatan hukum tetap untuk diangkat dan disahkan sebagai Gubernur melalui Menteri. DPRD Kabupaten/ Kota juga dapat menyampaikan kepada Menteri perihal penetapan Calon Bupati/Walikota Gubernur yang berhalangan tetap atau berhenti atau diberhentikan berdasarkan putusan pengadilan yang telah memperoleh kekuatan hukum tetap untuk diangkat dan disahkan sebagai Bupati/Walikota melalui Gubernur.

Plt yang telah diangkat pada kenyataannya memiliki kekuatan politik yang sangat lemah. Hal ini bisa dilihat dari contoh kasus di Kabupaten Pangandaran yang plt-nya dari Eselon II. Plt di Kabupaten Pangandaran tersebut dianggap masih yunior dan tidak mampu berkoordinasi dengan SKPD dan masyarakat karena pengalaman yang kurang serta tidak memiliki kekuatan politik.

Pengangkatan plt didasarkan pada kualifikasi yang telah ditetapkan oleh peraturan yang ada. Kualifikasi dari plt yang diangkat berdasarkan UU Nomor 8 Tahun 2015 pasal 201 ayat (8). Untuk mengisi kekosongan jabatan Gubernur yaitu berasal dari jabatan pimpinan tinggi madya. Dan pada UU Nomor 8 Tahun 2015 Pasal 201 ayat (9) juga disebutkan bahwa untuk mengisi kekosongan jabatan Bupati/ Walikota yaitu berasal dari jabatan pimpinan tinggi pratama. 
Sedangkan yang dimaksud dengan jabatan tinggi tersebut bisa mengacu pada UU Nomor 5 Tahun 2014 Pasal 19 tentang Aparatur Sipil Negara (ASN), yaitu:

1. Jabatan Tinggi Madya meliputi sekretaris jenderal kementerian, sekretaris kementerian, sekretaris utama, sekretaris jenderal kesekretariatan lembaga negara, sekretaris jenderal lembaga nonstruktural, direktur jenderal, deputi, inspektur jenderal, inspekturutama, kepalabadan, staf ahli menteri, Kepala Sekretariat Presiden, Kepala Sekretariat Wakil Presiden, Sekretaris Militer Presiden, Kepala Sekretariat Dewan Pertimbangan Presiden, sekretaris daerah provinsi, dan jabatan lain yang setara. Jabatan tinggi madya setara dengan Eselon I.

2. Jabatan Tinggi Pratama meliputi direktur, kepala biro, asisten deputi, sekretaris direktorat jenderal, sekretaris, inspektorat jenderal, sekretaris kepala badan, kepala pusat, inspektur, kepala balai besar, asisten sekretariat daerah provinsi, sekretaris daerah kabupaten/kota, kepala dinas/ kepala badan provinsi, sekretaris Dewan Perwakilan Rakyat Daerah, dan jabatan lain yang setara. Jabatan tinggi pratama setara dengan Eselon II.

Berdasarkan UU Nomor 30 Tahun 2014 tentang Administrasi Pemerintahan Pasal 14 ayat (1) dan (2), bahwa:
(1) Badan dan/atau Pejabat Pemerintahan memperoleh Mandat apabila:

a. ditugaskan oleh Badan dan/ atau Pejabat Pemerintahan di atasnya; dan

b. merupakan pelaksanaan tugas rutin.

(2) Pejabat yang melaksanakan tugas rutin sebagaimana dimaksud pada ayat (1) huruf $b$ terdiri atas:

a. pelaksana harian yang melaksanakan tugas rutin dari pejabat definitif yang berhalangan sementara; dan

b. pelaksana tugas yang melaksanakan tugas rutin dari pejabat definitif yang berhalangan tetap.

Dalam menjalankan roda pemerintahan, wewenang plt sangat dibatasi. Batas kewenangan plt berdasarkan Pasal 132 A ayat (1), Peraturan Pemerintah Nomor 49 Tahun 2008 tentang Perubahan Ketiga atas Peraturan Pemerintah Nomor 6 Tahun 2005 tentang Pemilihan, Pengesahan Pengangkatan, dan Pemberhentian Kepala Daerah dan Wakil Kepala Daerah, yaitu:

1. Melakukan mutasi pegawai;

2. Membatalkan perijinan yang telah dikeluarkan pejabat sebelumnya dan/atau mengeluarkan perijinan yang bertentangan dengan yang dikeluarkan pejabat sebelumnya;

3. Membuat kebijakan tentang pemekaran daerah yang bertentangan dengan kebijakan pejabat sebelumnya; dan 
4. Membuat kebijakan yang bertentangan dengan kebijakan penyelenggaraan pemerintahan dan program pembangunan pejabat sebelumnya.

Namun keempat larangan tersebut dapat dikecualikan bila ada izin dari Menteri Dalam Negeri (Pasal 132 A ayat (2) Peraturan Pemerintah Nomor 49 Tahun 2008).

Berdasarkan UU Nomor 30 tahun 2014 tentang Administrasi Pemerintahan Pasal 14 ayat (7) bahwa Badan dan/atau Pejabat Pemerintahan yang memperoleh Wewenang melalui Mandat tidak berwenang mengambil Keputusan dan/atau Tindakan yang bersifat strategis yang berdampak pada perubahan status hukum pada aspek organisasi, kepegawaian, dan alokasi anggaran. Dalam penjelasan Pasal 14 ayat (7) dinyatakan bahwa yang dimaksud dengan "Keputusan dan/atau Tindakan yang bersifat strategis" adalah Keputusan dan/atau Tindakan yang memiliki dampak besar seperti penetapan perubahan rencana strategis dan rencana kerja pemerintah. Yang dimaksud dengan "perubahan status hukum organisasi" adalah menetapkan perubahan struktur organisasi. Yang dimaksud dengan "perubahan status hukum kepegawaian" adalah melakukan pengangkatan, pemindahan, dan pemberhentian pegawai. Yang dimaksud dengan "perubahan alokasi anggaran" adalah melakukan perubahan anggaran yang sudah ditetapkan alokasinya.
Dalam UU Nomor 30 Tahun 2014 Pasal 17 ayat (2) bahwa pejabat pemerintah dilarang menyalahgunakan wewenang meliputi larangan melampaui wewenang, larangan mencampuradukkan wewenang, dan larangan bertindak sewenang-wenang.

Kewenangan plt memang dibatasi pada hal-hal yang bersifat strategis karena ia hanya bersifat sebagai pelanjut roda pemerintahan bukan Kepala Daerah Definitif. Adanya batasan kewenangan tersebut nantinya akan berakibat pada terhambatnya roda pemerintahan, apalagi akan ada beberapa daerah yang akan dipimpin oleh plt selama kurang lebih dua tahun.

Jika selama masa transisi diperlukan suatu kebijakan strategis yang harus diambil oleh plt, maka Pasal 132 A ayat (2) Peraturan Pemerintah Nomor 49 Tahun 2008 bisa dijadikan dasar untuk mengambil kebijakan tersebut setelah meminta izin terlebih dahulu dari Menteri Dalam Negeri. Namun, Pasal 132 A ayat (2) Peraturan Pemerintah Nomor 49 Tahun 2008 masih belum terlalu jelas membahas mengenai wewenang plt sehingga perlu adanya suatu aturan agar plt dapat mengambil kebijakan strategis dalam pemerintahan terutama plt yang akan menjalankan tugas selama atau lebih dari dua tahun. Pemerintah bisa saja mengeluarkan Diskresi atau PP untuk mengatur masalah plt agar adanya kewenangan plt dalam pengambilan kebijakan strategis tetapi jangan sampai 
kepentingan politik pemerintah pusat masuk ke dalamnya.

Pada dasarnya pemerintah pusat diuntungkan dengan adanya plt karena plt dapat membantu tugas pemerintah pusat dan juga bertanggung-jawab kepada pemerintah pusat. Dengan banyak plt yang ditunjuk oleh pemerintah pusat, maka ditakutkan kepentingan politik dari pemerintah pusat masuk melalui plt yang telah diangkat.

Mengenai sanksi bagi plt yang menyalahgunakan wewenang, sebenarnya belum ada pengaturan yang jelas, namun berdasarkan UU Nomor 30 tahun 2014 tentang Administrasi Pemerintahan Pasal 80 ayat (3) bahwa penyalahgunaan wewenang yang dilakukan oleh pejabat pemerintah sesuai dengan Pasal 17 UU Nomor 30 Tahun 2014, akan dikenai sanksi administratif berat. Sanksinya sesuai dengan pasal 81 ayat (3) UU Nomor 30 Tahun 2014, yaitu:

1. pemberhentian tetap dengan memperoleh hak-hak keuangan dan fasilitas lainnya;

2. pemberhentian tetap tanpa memperoleh hak-hak keuangan dan fasilitas lainnya;

3. pemberhentian tetap dengan memperoleh hak-hak keuangan dan fasilitas lainnya serta dipublikasikan di media massa; atau

4. pemberhentian tetap tanpa memperoleh hak-hak keuangan dan fasilitas lainnya serta dipublikasikan di media massa.

Pemberian sanksi berat dijatuhkan setelah dilakukan proses pemeriksaan internal (Pasal 83 ayat (4) UU Nomor 30 Tahun 2014).

Plt jikalau bersifat pemberian mandat, maka ia dilindungi oleh UU Nomor 30 Tahun 2014, karena ia bertanggung-jawab kepada pemberi mandat. Dalam hal ini pun sebenarnya dibutuhkan peraturan yang jelas untuk melindungi plt.

Dikaitkan dengan situasi terakhir perekonomian Indonesia, telah terjadi melemahnya dorongan ekspor, tekanan pada stabilitas ekonomi, dan rendahnya penyerapan anggaran yang akan berpengaruh terhadap perlambatan ekonomi. ${ }^{109}$ Bila dikaitkan dengan plt kepala daerah ini yang tidak boleh melakukan tindakan stategis, tentu akan menambah buruk situasi ekonomi Indonesia dengan banyaknya anggaran yang tidak terserap. Potensi belanja negara yang mengendap ini menurut Hefrizal Handra ${ }^{110}$, di antara penyebabnya adalah karena juknis dan juklak yang terlalu rinci. Namun

109 Bambang Prijambodo, Catatan Singkat Tantangan Perekonomian Global dan Percepatan Pembangunan Daerah, Kertas Kerja dalam Seminar Budget Office DPD RI, 3 September 2015. 110 Hefrizal Handra, Analisis Ekonomi Makro dan RAPBN 2016, kertas kerja dalam Seminar Budget Office DPR RI, Jakarta 3 September 2015. 
menurut penulis justru dalam persoalan plt ini regulasinya yang belum ada dan perlu dirumuskan dengan jelas.

\section{Kesimpulan}

Kesimpulan yang dapat diambil dari uraian di atas adalah:

1. Pengangkatan plt Gubernur diangkat oleh Presiden melalui usulan Menteri Dalam Negeri. Sedangkan pengangkatan Bupati/ Walikota diangkat oleh Menteri Dalam Negeri melalui usulan oleh Gubernur.

2. Kualifikasi dari plt yang diangkat berdasarkan UU Nomor 8 Tahun 2015 pasal 201 ayat (8) untuk mengisi kekosongan jabatan Gubernur yaitu berasal dari jabatan pimpinan tinggi madya. Dan pada UU Nomor 8 Tahun 2015 pasal 201 ayat (9) bahwa untuk mengisi kekosongan jabatan Bupati/Walikota yaitu berasal dari jabatan pimpinan tinggi pratama.

3. Batas kewenangan plt terdapat dalam Pasal 132 A Peraturan Pemerintah Nomor 49 Tahun 2008 tentang Perubahan Ketiga atas Peraturan Pemerintah Nomor 6 Tahun 2005 tentang Pemilihan, Pengesahan Pengangkatan, dan Pemberhentian Kepala Daerah dan Wakil Kepala Daerah dan UU Nomor 30 tahun 2014 tentang Administrasi Pemerintahan Pasal 14 ayat (7).
4. Jika selama masa transisi diperlukan suatu kebijakan strategis yang harus diambil oleh plt, maka diatur oleh Pasal 132 A ayat (2) Peraturan Pemerintah Nomor 49 Tahun 2008 tentang Perubahan Ketiga atas Peraturan Pemerintah Nomor 6 Tahun 2005 tentang Pemilihan, Pengesahan Pengangkatan, dan Pemberhentian Kepala Daerah dan Wakil Kepala Daerah, yaitu harus seizin Mendagri.

5. Mengenai sanksi bagi plt yang menyalahgunakan wewenang, sebenarnya belum ada pengaturan yang jelas seiring ketidakjelasan jenis kewenangan yang diberikan kepada plt.

6. Bilamana kewenangan plt bersifat pemberian mandat, maka ia dilindungi oleh UU Nomor 30 Tahun 2014, karena ia bertanggung-jawab kepada pemberi mandat.

\section{Saran}

Problematika plt kalau tidak cepat diatur, bisa menjadi bom waktu yang dapat menghambat jalannya roda pemerintahan dan berpengaruh terhadap perlambatan ekonomi. Pemerintah seharusnya membuat peraturan yang khusus dan jelas mengenai plt ini jangan seperti sekarang tersebar dalam berbagai aturan, pemerintah bisa saja mengeluarkan Diskresi atau PP jikalau seandainya Perpu belum dianggap penting untuk dikeluarkan. 
Bisa pula dilakukan Perubahan Kedua atas UU No. 1 Tahun 2015 (Perubahan Pertama UU No. 8 Tahun 2015) yang penting materi muatan PP khusus tentang Pelaksana Tugas ini atau Perubahan Kedua UU harus secara tegas mengatur:

a. Pejabat yang berhak mengangkat plt jika terjadi kekosongan jabatan kepala daerah selama masa transisi.

b. Kualifikasi dari plt yang diangkat.

c. Batas kewenangan plt.

d. Apa yang harus dilakukan oleh plt jika selama masa transisi diperlukan suatu kebijakan strategis.

e. Kejelasan secara terinci apa saja yang merupakan kebijakan strategis tersebut (perluasan Pasal 132 A ayat (1)

f. Demikian pula rincian Keputusan dan/atau Tindakan yang bersifat strategis yang berdampak pada perubahan status hukum pada aspek organisasi, kepegawaian, dan alokasi anggaran itu seperti apa saja.

g. Sanksi yang diberikan kepada plt yang melakukan sesuatu diluar kewenangan (bila produk hukum yang dipilih UU Perubahan).

h. Perlindungan hukum bagi plt dalam melaksanakan tugasnya.

i. Ketegasan pelimpahan wewenang atribusi, delegasi, atau mandat bagi si plt.

j. Agar tidak terjadi kekhawatiran dari para ahli ekonomi tentang anggaran yang tidak terserap/ mengendap di daerah maka persoalan kewenangan plt tentang anggaran ini harus didudukkan secara khusus sekaligus menjadi perlindungan hukum bagi plt dalam melaksanakan tugasnya.

\section{Daftar Pustaka}

Buku:

Labolo, Muhammad, 2013. Memahami Ilmu Pemerintahan (Suatu Kajian, Teori, Konsep, dan Pengembangannya). Jakarta: PT. Raja Grafindo Persada.

Moleong, 2006. Metodologi Penelitian Kualitatif. Bandung: PT Remaja Rosdakarya.

\section{Sumber Lain:}

Bambang Prijambodo, Catatan Singkat Tantangan Perekonomian Global dan Percepatan Pembangunan Daerah, Kertas Kerja dalam Seminar Budget Office DPD RI 3 September 2015.

Hefrizal Handra, Analisis Ekonomi Makro dan RAPBN 2016, kertas kerja dalam Seminar Budget Office DPR RI, Jakarta 3 September 2015.

Manan, Bagir, 1999. Penelitian Di Bidang Hukum, artikel dalam Jurnal Hukum. Puslitbangkum Lembaga Penelitian Universitas Padjadjaran Nomor Perdana: 1-1999. 
Randy Ghalib, Memahami Kewenangan Plt atau Pj Kepala Daerah, Diposting 07 Agustus 2015, 14:38:24 Dibaca: 302 pertama publish di Group Facebook Aku Cinta Maluku Utara (ACMU), Diunduh tanggal 10 September 2015 oleh Penulis. http://www.otda.kemendagri. go.id/.
TOR LAN RI, 2015. Hasil Wawancara dengan staf Gubernur Jawa Barat, Prof. Dr. H. Dede Mariana, Drs., M.Si., 14 September 2015. 